\title{
Daya Dukung dan Efisiensi Produksi Sapi Madura dengan Pemanfaatan Limbah Kacang Kedalai
}

\author{
Carry Capacity and Efficiency Production of Madura Cattle Through Utilization \\ Soybean Waste
}

\section{S. A. Rab $^{1)}$ R. Priyanto ${ }^{2)}$ A. M. Fuah ${ }^{2)}$ dan I K G Wiryawan ${ }^{3)}$}

1) Mahasiswa Program Studi Ilmu Produksi dan Teknologi Peternakan, Sekolah Pascasarjana, Institut Pertanian Bogor; 2) Departemen Ilmu Produksi dan Teknologi Peternakan, Fakultas Peternakan, Institut Pertanian Bogor; 3) Departemen Ilmu Nutrisi dan Teknologi Pakan,

Fakultas Peternakan, Istitut Pertanian Bogor

Jln. Agatis, Kampus IPB Dramaga, Bogor 16680.

\begin{abstract}
The aim of this study was to evaluate productivity of beef cattle through the utilization soybean by-product.Twelve Madura cattle with and average initial liveweight of $175.64 \pm 16.41 \mathrm{~kg}$ and aged between I1-I2 (18-30 months) were used in this study fattened for three monthsgiven differentfeeds level, ie. P0 (100\% native grass), $\mathrm{P} 1(40 \%$ roughage $+60 \%$ concentrate), $\mathrm{P} 2(15 \%$ of soybean pod $+85 \%$ concentrate), and $\mathrm{P} 3(30 \%$ soybean pod $+70 \%$ concentrate). Observed parameters included production of soybean waste per hektar, carry capacity of cattle based of soybean waste, income over feed cost (IOFC), andRC ratio.The results showed that the production of soybean pods and tofu waste was 1.75 ton/ha, and 0.44 ton/ha. This results indicated that carry capasity of soybean wastes for cattle production was of8,95 ST/ha/year, and 1,91 ST/ha/year respentively. Economy analisis based on income over feed cost and $\mathrm{R} / \mathrm{C}$ ratio results showed that use of soybean waste was to replaces forage quite potensial for farmer, especially in the region to here soybean production is high.
\end{abstract}

Keywords: production of soybean, income over feed cost, R-C ratio,local cattle.

\section{PENDAHULUAN}

Sapi potong merupakan salah satu ternakyang perlu ditingkatkan di Indonesia,untuk memenuhi kebutuhan daging dalam negeri. Kebutuhan daging di Indonesia setiap tahun mengalami peningkatantetapi tidak diimbangi dengan produksi daging dalam negeri. Konsumsi daging segar per kapita pada tahun 2014 sebesar $5.005 \mathrm{~kg}$, atau meningkat sebesar 6,65 persendari konsumsi tahun 2013 sebesar 4.693 kg (BPS, 2014). Dirjen Peternakan (2014) menyatakan bahwa secara nasional konsumsi daging sapi pada tahun 2015, diperkirakan mencapai 653.982 ton daging atau setara 3. 843. 787 ekor sapi sedangkan potensi dalam negeri hanya 2. 445 . 577 ekor atau setara 416.090 ton daging. Sehingga, masih defisit 1,39 juta ekor sapi atau setara dengan 237,89 ton daging sapi.

Keterbatasan lahan, modal, manajemen dan teknologi mengakibatkan produktivitas ternak sapi masih rendah. Angka kelahiran ternak baru mencapai 21\% (potensi $30 \%$ ) dari populasi, jarak beranak cukup panjang sekitar 1821 bulan (potensi 15 bulan), berat karkas sapi lokal yang hanya $156 \mathrm{~kg}$ (sapi potong hasil IB dan sapi impor sebesar 221 kg/ekor) (Luthan, 2009).Masalah utama dibalik rendahnya produktivitas sapi potong, karena kurangnya kecukupan sumber pakan, rendahnya kualitas nutrisi pakan yang tersedia, terutama pada saat musim kemarau. Ada beberapa strategi yang diperlukan untuk meningkatkan produktivitas sapi potong,antara lain adalah dari pakan kedelai.Pakan kedelai mengandung protein kasar yang tinggi, yaitu sekitar $44 \%$ dengan asam amino yang seimbang.Kennedy (2012) melaporkan bahwa penggunaan $15 \%$ bungkil kedelai dalam ransum domba dikombinasikan dengan tongkol jagung meningkatkan keuntungan rata-rata harian domba.Luas lahan kedelai di Indonesia pada tahun 2014 adalah 615 ribu hektar, di pulau Jawa seluas 379 ribu hektar dan di luar pulau Jawa 236 ribu hektar. Produksi kedelai tahun 2014 sebanyak 953,96 ribu ton, meningkat sebanyak 173,96 ribu ton dibandingkan tahun 2013. Peningkatan produksi kedelai tersebut terjadi di pulau Jawa sebanyak 100,20 ribu ton dan di luar pulau Jawa sebanyak 73,76 ribu ton. Peningkatan produksi kedelai terjadi karena kenaikan luas panen seluas 64,23 ribu hektar (11,66 persen) dan kenaikan produktivitas sebesar 1,35 kuintal/hektar (9,53 persen)(BPS, 2014).

Integrasi antara sapi dan kedelai dapat menjadi salah satu solusi alternatif untuk meningkatkan produksi sapi potong dan juga untuk meningkatkan efisiensi pakan. Asnath et al.,(2016) menjelaskan bahwa dengan pemberian ransum $15 \%$ kulit polong kedelai memiliki nilai performa terbaik pada sapi Madura. Tujuan penelitian ini adalahmengevaluasi produktivitas sapi lokal dengan 
pemberian pakan limbah kacang kedelai.

\section{METODE PENELITIAN}

\section{Waktu dan Tempat Penelitian}

Penelitian dilaksanakan dari bulan Juni sampai November 2015. Pemeliharaan dilaksanakan di Laboratorium Lapang BlokA Ruminansia Besar,Departemen Ilmu Produksi dan Teknologi Peternakan, Institut Pertanian Bogor.

\section{Materi Penelitian}

Ternak yang digunakan dalam penelitian ini adalah bakalan sapi lokal (Sapi Madura) sebanyak 12 ekor dengan bobot awal 145-204 kg/ekor. Umur bakalan sapi lokal umur sapi I1-I2 (18-30 bulan).

Pakan yang digunakan selama penelitian berupa hijauan, kulit polong kacang kedelai, dan konsentrat. Hijauan pakan ternak diperoleh di kebun rumput IPB, kulit polong kacang kedelai diperoleh dari Kabupaten Grobogan, Provinsi Jawa Tengah, dan konsentrat dibuat di Laboratorium Blok A Ruminansia, Fakultas Peternakan IPB. Bahan baku konsentrat diperoleh dari penjual pakan di daerah Bogor. Bahan baku konsentrat yang digunakan terdiri atas onggok, pollard, bungkil kedelai, molases, $\mathrm{CaCO} 3$, urea, ampas tahu dan premix. Komposisi bahan pakan dan kandungan nutrien ransum tercantum pada Tabel 1 dan 2.

\section{Persiapan bahan}

\section{ProsedurPenelitian}

Sebelum penelitian dilakukan peralatan dan bahan

Tabel 1. Komposisi bahan pakan penelitian berdasarkan bahan kering

\begin{tabular}{lcccc}
\hline Bahan pakan & \multicolumn{4}{c}{ Perlakuan } \\
\cline { 2 - 5 } & P0(\%) & P1(\%) & P2(\%) & P3(\%) \\
\hline Rumput & 100 & 40 & - & - \\
Kulit polong kedelai & - & - & 15 & 30 \\
Konsentrat & - & 60 & 85 & 70 \\
Bahan penyusun konsen- & & & & \\
trat & - & 21 & 20 & 10 \\
Onggok & - & 19,2 & 22 & 15 \\
Pollard & - & 3 & 5 & 7 \\
Bungkil kedelai & - & 6 & 0 & 0 \\
Bungkil kelapa & - & 9 & 15 & 15 \\
Molasses & - & 0,9 & 1,5 & 1,5 \\
CaCO3 & - & 0,6 & 1 & 1 \\
Urea & - & - & 20 & 20 \\
Ampas tahu & - & 0,3 & 0,5 & 0,5 \\
Premix & 100 & 100 & 100 & 100 \\
Jumlah &
\end{tabular}

Sumber : Hasil Analisa Proksimat Laboratorium Biologi Hewan, Pusat Penelitian Sumberdaya Hayati dan Bioteknologi, Institut Pertanian Bogor (2015).P0: rumput $100 \%$, P1: konsentrat $(60 \%)+$ rumput $(40 \%), \mathrm{P} 2$ : konsentrat $(85 \%)+$ kulit polong kedelai $(15 \%), \mathrm{P} 3$ : konsentrat $(70 \%)+$ kulit polong kedelai $(30 \%)$.
Tabel 2. Kandungan nutrien ransum penelitian berdasarkan bahan kering

\begin{tabular}{lcccc}
\hline Kandungan nutrisi & \multicolumn{4}{c}{ Perlakuan (\%) } \\
\cline { 2 - 5 } & P0 & P1 & P2 & P3 \\
\hline BK & 22,2 & 60,1 & 72,2 & 73,9 \\
Abu & 11,7 & 3,2 & 5,4 & 5,7 \\
PK & 8 & 12 & 14 & 14,2 \\
LK & 1,6 & 3,3 & 4,6 & 5 \\
SK & 34 & 20,6 & 17,1 & 21 \\
Beta-N & 34,7 & 52,4 & 55,8 & 51,2 \\
TDN & 54,3 & 66,3 & 71 & 68 \\
\hline
\end{tabular}

BK : bahan kering, PK: protein kasar, LK: lemak kasar, SK: serat kasar, TDN: total digestible nutrien. P0: rumput $100 \%$, P1: konsentrat $(60 \%)+$ rumput $(40 \%), \mathrm{P} 2$ : konsentrat $(85 \%)+$ kulit polong kedelai $(15 \%), \mathrm{P} 3$ : konsentrat $(70 \%)$ + kulit polong kedelai $(30 \%)$.

disiapkan, yang meliputi : persiapan bahan pakan, kandang, peralatan, dan obat-obatan. Ternak sapi yang digunakan terlebih dahulu diberi obat cacing, dan vitamin B-kompleks. Sebelum perlakuan diberikan, dilakukan adaptasi pakan selama 14 hari. Sapi Madura sebanyak 12 ekor dengan bobot badan 145-204 kg ditempatkan didalam kandang individu untuk mendapatkan perlakuan pakan. Ternak sapi diacak berdasarkan bobot badan menjadi empat kelompok dengan tiga ulangan untuk mendapatkan perlakuan pakan selama 90 hari pemeliharaan

\section{Perlakuan}

Jenis perlakuan pakan sebagai berikut : (P0) rumput $100 \%$, (P1) konsentrat $(60 \%)+$ rumput $(40 \%)$, (P2) konsentrat $(85 \%)+$ kulit polong kedelai $(15 \%)$, dan (P3) konsentrat (70\%) + kulit polong kedelai (30\%). Frekuensi pemberian pakan sebanyak enam kali dengan selang waktu 06.00-08.00 WIB, pukul 09.00-11.00 WIB, pukul 13.00-15.00 WIB, pukul 16.00-18.00 WIB, pukul 19.00-20.00 WIB, dan terakhir pada pukul 22.00 WIB. Sisa pemberian pakan ditimbang dan dicatat untuk memperoleh data konsumsi pakan. Penimbangan ternak sapi dilakukan perbulan untuk mendapatkan data bobot badan

Data produksi limbah kacang kedelai diperoleh dengan melakukan survei pada lokasi tanaman kedelai dan wawancara dengan pengrajin tahu. Produksi kulit polong kedelai diketahui dengan menggunakan cuplikan (ubinan) yang siap panen. Hasil ubinan kulit polong kedelai merupakan produktivitas kulit polong kedelai yang diperoleh dari petak ubinan seluas 6,25 m2 (2,5 m x 2,5 m) dikalikan dengan luas tanam tanaman kedelai pada bidang yang sama. Berat hasil tanaman padi dalam satuan $\mathrm{kg}$ per m2 kemudian dikalikan dengan luas tanam tanaman kedelai pada bidang yang sama dimana terdapat petak ubinan. Berat hasil kulit polong kedelai merupakan estimasi terhadap hasil panen tanamankedelai pada bidang tersebut. Setiap hasil ubinan akan dilakukan pencatatan data.

\section{Sumber Data}

Data primer diperoleh dari hasil survei dan wawancara, yaitu produksi kulit polong kedelai dan ampas tahu. Data-data sekunder yang berhubungan dengan 
tujuan kajian ini diperoleh dari hasil penelitian-penelitian sebelumnya dan hasil penelitian Asnath et al.,(2016) terkait dengan konsumsi pakan, pertambahan bobot badan harian, dan efisiensi pakan. Data pendukung yang berkaitan dengan penelitian ini diperoleh dari berbagai sumber pustaka.

\section{Analisis Data}

\section{Model}

Rancangan yang digunakan dalam penelitian adalah Rancangan Acak Kelompok (RAK). Model rancangan menurut Matjik dan Sumertajaya (2002) adalah sebagai berikut :

$$
Y \mathbf{i j}=\mu+\alpha \mathbf{i}+\beta \mathbf{j}+\varepsilon \mathbf{i j}
$$

Keterangan:

Yij = Kinerja produksi dan kualitas karkas sapi lokal dalam sistem integrasi dengan kacang kedelai ke-i (pakan $100 \%$ rumput, rumput $40 \%+$ konsentrat $60 \%$, ransum $15 \%$ kulit polong kedelai, dan ransum 30\% kulit polong kedelai ) pada kelompok ke-j $(1,2,3$, dan 4)

$\mathrm{i} \quad=$ Perlakuan 1,2,3,4 (banyaknya perlakuan)

$\mathrm{j} \quad=$ Kelompok 1,2,3,4 (banyaknya kelompok)

$\mu \quad=$ Nilai tengah dari semua perlakuan

$\alpha \mathrm{i}=$ Pengaruh perlakuan ke-i

$\beta \mathrm{j} \quad=$ Pengaruh kelompok ke-j

घij = Pengaruh acak pada perlakuan ke-i dankelompok ke-j

\section{Analisis Data}

Data dianalisis dengan menggunakan analysis of covariance Kovariabel yang digunakan yaitu bobot awal. Apabila terdapat pengaruh nyata terhadap peubah yang diamati dilanjutkan dengan menggunakan uji Least Square Means. Data daya dukung limbah dihitung menggunakan hasil analisis produksi limbah/ha.

\section{Produksi limbah kacang kedelai.}

\section{Peubah yang Diamati}

Produksi limbah tanaman ini dihitung berdasarkan produksi segar dan bahan kering (BK). Berdasarkan data luas areal panen (ha), dilakukan perhitunganproduksi masing-masing limbah tanaman mengacu pada Syamsu et al 2006.

Total Produksi Segar $=$ Produksi segar $($ ton $/$ ha $) \times$ luas areal panen (Ha)

Total Produksi Kering $=$ Produksi Kering(ton/Ha) $\times$ Luas Areal Panen (Ha)

\section{Income over feed cost}

Income over feed cost dihitung dari selisih penerimaan dengan pengeluaran selama pemeliharaan. Penerimaan dihitung dari perkalian rataan $\mathrm{PBBH}$ dengan harga sapi $/ \mathrm{kg}$, sedangkan pengeluaran dihitung dari perkalian rataan konsumsi pakan as fed/ekor dengan harga ransum masing-masing sapi percobaan.

\section{$\mathrm{R}-\mathrm{C}$ ratio}

$$
\mathrm{IOFC}=\text { Penerimaan }(\mathrm{Rp})-\text { pengeluaran }(\mathrm{Rp})
$$

$\mathrm{R}-\mathrm{C}$ ratio diperoleh dari perbandingan antara penerimaan dan pengeluaran (tabel 3). Penerimaan diperoleh dari pertambahan bobot badan per harinya dikalikan dengan harga jual sapi per kilogram bobot hidup, sedangkan pengeluaran diperoleh dari biaya pembuatan ransum setiap perlakuan dikalikan konsumsi as fed (kg/ekor/hari). Berikut rumus yang digunakan untuk menghitung $\mathrm{R}-\mathrm{C}$ ratio:

$$
\mathrm{A}=\mathrm{R} / \mathrm{C}
$$

Keterangan :
A : Revenue Cost Ratio
$\mathrm{R}$ : total penerimaan
$\mathrm{C}$ : total biaya pengeluaran

\section{Daya dukung limbah kacang kedelai sebagai pakan} ternak.

Menghitung daya dukung limbah tanaman pangan (DDLTP)digunakan asumsi kebutuhan pakan ternak sapi. Asumsi yang digunakan yaitu Satu Satuan Ternak (1 ST) ternak sapi rata-rata membutuhkan Bahan Kering (BK) adalah 6,25 Kg/hari (NRC, 1984). Daya dukung limbah tanaman (DDLTP) dihitung dengan menggunakan rumus dari (Syamsu et al., 2006). yaitu sebagai berikut :

$$
\begin{aligned}
& \operatorname{DDLTP}(\mathrm{BK})=\frac{\text { Produksi BK }(\text { ton/tahun })}{\text { Kebutuhan BK 1 ST (ton/tahun) }} \\
& \text { Ket }: \text { DDLTP }=\text { Daya dukung limbah tanaman pertanian, } \\
& \text { BK }=\text { Bahan kering, }
\end{aligned}
$$

\section{HASIL DAN PEMBAHASAN}

\section{Produksi Limbah Tanaman Kacang kedelai}

Tanaman kacang kedelai merupakan salah satu komoditas pangan yang sangat penting di Indonesia. Kacang kedelai menjadi program swasembada dari pemerintah selain padi, dan jagung. Salah satu sasaran dari pemerintah yaitu swasembada padi, jagung, dan kedelai serta peningkatan produksi daging dan gula (RENSTRA, 2015). Tanaman kacang kedelai, selain biji kedelai sebagai produk utama, tanaman kacang kedelai juga menghasilkan limbah yang bisa dimanfaatkan sebagai pakan ternak atau sebagai bahan sumber pakan alternatif. Hasil survei produksi limbah kacang kedelai, diperoleh produksi segar, dan produksi bahan kering disajikan pada tabel 3 .

Hasil pengamatan produksi segar kulit polong kedelai yaitu 1.81 ton/ha, dan produksi bahan keringnya 1.75 ton/ha. Produksi segar ampas tahu yaitu 3.04 ton/ ha, sedangkan produksi bahan kering ampas tahu sebesar 0.44 ton/ha (Tabel 3). Hasil penelitian ini lebih rendah dibandingkan produksi limbah jerami padi. Seperti yang dilaporkan oleh Haryanto et al., (2002) bahwa jerami padi segar yang dihasilkan dapat mencapai 5 ton/ha setiap kali panen. Selain itu Syamsu et al (2006) melaporkan bahwa produksi limbah jerami padi, jerami jagung, jerami kedelai, jerami kacang hijau, jerami ubi jalar, dan pucuk ubi kayu dalam bahan kering masing-masing sebesar 5.95 ton/ha, 6

Tabel 3. Produksi segar, dan produksi bahan kering limbah kacang kedelai

\begin{tabular}{lcc}
\hline Limbah kedelai & \multicolumn{2}{c}{ Produksi } \\
\cline { 2 - 3 } & Produksi Segar & Produksi BK \\
\hline Kulit polong kedelai (ton/ha) & $1,81 \pm 0,65$ & $1,75 \pm 0,63$ \\
Ampas tahu (ton/ha) & 3,04 & 0,44 \\
\hline
\end{tabular}

Keterangan : Produksi biji kedelai $=2,75$ ton/ha/tahun, $\mathrm{BK}=$ bahan kering, $\mathrm{KPKK}=$ kulit polong kacang kedelai, $\mathrm{AT}=$ ampas tahu 
Tabel 4. Konsumsi nutrisi dan performa sapi lokal yang diberikan pakan limbah kacang kedelai

\begin{tabular}{lcccc}
\hline Peubah & \multicolumn{3}{c}{ Perlakuan } \\
\cline { 2 - 5 } & P0 & P1 & P2 & P3 \\
\hline Konsumsi BK (kg/ekor/hari)* & $4,63 \pm 0,24 \mathrm{~B}$ & $6,36 \pm 0,29 \mathrm{~A}$ & $6,92 \pm 0,24 \mathrm{~B}$ & $6,67 \pm 0,24 \mathrm{~B}$ \\
PBBH (kg/ekor/hari)* & $0,26 \pm 0,06 \mathrm{~B}$ & $0,71 \pm 0,08 \mathrm{~A}$ & $0,73 \pm 0,06 \mathrm{~A}$ & $0,64 \pm 0,06 \mathrm{~A}$ \\
Efisiensi Pakan (\%)* & $5,54 \pm 1,00$ & $9,83 \pm 1,23$ & $9,82 \pm 1,00$ & $8,86 \pm 1,00$ \\
IOFC (Rp) & $9831 \pm 3221 \mathrm{~B}$ & $27216 \pm 3972 \mathrm{~A}$ & $9104 \pm 3218 \mathrm{~B}$ & $7231 \pm 3219 \mathrm{~B}$ \\
R-C ratio & $3,05 \pm 0,39 \mathrm{~B}$ & $4,41 \pm 0,5 \mathrm{~A}$ & $1,33 \pm 0,39 \mathrm{~B}$ & $1,32 \pm 0,39 \mathrm{~B}$ \\
\hline
\end{tabular}

Data dikoreksi dengan rataan bobot awal $175 \mathrm{~kg}$. Angka-angka pada baris yang sama yang diikuti oleh huruf yang berbeda menunjukkan perbedaan nyata $(\mathrm{P}<0,05) \mathrm{BK}$ : bahan kering, $\mathrm{PK}$ : protein kasar, TDN: total digestible nutrient, $\mathrm{PBBH}$ : pertambahan bobot badan harian. *Data konsumsi BK, PBBH, dan Efisiensi pakan (Asnath et al., 2016)

ton/ha, 2.79 ton/ha, 5.45 ton/ha, 4.94 ton/ha, 4.93 ton/ha, dan 1.73 ton/ha.

Luas lahan tanaman kedelai di pulau Jawa adalah 379 ribu hektar (BPS, 2014). Produktivitas tanaman kedelai rata-rata 2-3 ton/ha biji kering. Produksi kulit polong kedelai sebesar 1.75 ton/ ha. Luas tanaman kedelai yang luasnya 379 ribu hektar berpotensi menghasilkan 663.250 ton bahan kering kulit polong kedelai. Apabila dimanfaatkan sebagai sumber pakan, maka dapat memberi pakan 1.188.620.07 ekor sapi, dengan asumsi setiap ekor sapi membutuhkan $6.20 \mathrm{~kg}$ bahan kering/hari. Hal ini menujukkan kulit polong kedelai memiliki potensi untuk dijadikan sebagai pakan ternak untuk menggantikan hijauan terutama pada saat musim kemarau.

\section{Income Over Feed Cost (IOFC)}

Ternak sapi yang diberi perlakuan menggunakan pakan kulit polong kedelai memberikan perngaruh nyata terhadap nilai IOFC $(\mathrm{P}<0.05)$. Hasil dapat dilihat pada Tabel 4. diperoleh nilai IOFC perlakuan P0 ( Rp9 831 per ekor/hari ), P1 (Rp27 216 per ekor/hari), P2 (Rp9 104 per ekor/hari), P3 (Rp7 231 per ekor/hari). Perlakuan P2 memiliki nilai IOFC tertinggi sebesar Rp27 216 per ekor/ hari. Jadi ransum perlakuan P1 (rumput 40\%+konsentrat $60 \%$ ) memiliki nilai ekonomis yang lebih tinggi. Hal ini disebakan karena pada perlakuan P1 harga ransum rendah dan memiliki PBBH yang tinggi. Nurdiati et al., (2012) menyatakan bahwa keuntungan yang kecil disebabkan oleh income yang berasal dari PBBH yang rendah, sehingga hal-hal yang mempengaruhi $\mathrm{PBBH}$ perlu diperhatikan untuk mendaptkan PBBH yang maksimal. Perlakuan yang memiliki nilai IOFC terendah adalah perlakuan P3 (ransum $30 \%$ kulit polong kedelai). Keuntungan yang rendah pada perlakuan P3 diduga karena biaya pakan yang terlalu tinggi yang tidak diimbangi dengan pemasukan. Suharno dan Afandi (2009) menyatakan bahwa walaupun PBBH yang dihasilkan tinggi tetapi biaya produksi juga tinggi, akan tetap menghasilkan income yang rendah. Ada beberapa faktor yang berpengaruh dalam perhitungan IOFC adalah pertambahan bobot badan, konsumsi pakan dan harga pakan selama pemeliharaan. Menurut Astutik et al., (2002) IOFC dihitung karena biaya pakan berkisar antara 60\%-80\% dari biaya total produk. Biaya pakan yang rendah diikuti dengan pertumbuhan dan efisiensi pakan yang baik akan menghasilkan keuntungan yang maksimal.

\section{R-C Ratio}

Usaha ternak menguntungkan apabila nilai $\mathrm{R}-\mathrm{C}$ ratio lebih dari 1 , sebaliknya jika $\mathrm{R}-\mathrm{C}$ rationya kurang dari 1 maka usaha tersebut tidak efisien atau merugikan (Teken \& Asnawi 1983). Semakin besar nilai R-C ratio maka semakin besar pula tingkat efisiensi ekonomi peternakan sapi potong. Nilai R-C ratio ternak sapi yang diberi pakan limbah kacang kedelai dapat dilihat pada Tabel 4. Perlakuan sangat berpengaruh nyata terhadap nilai R-C ratio $(\mathrm{P}<0.01)$. Hasil perhitungan $\mathrm{R}-\mathrm{C}$ ratio $\mathrm{P} 0, \mathrm{P} 1, \mathrm{P} 2$, dan $\mathrm{P} 3$ berturutturut $2.32,3.35,1.01$, dan 1 . Nilai $\mathrm{R}-\mathrm{C}$ ratio tertinggi yaitu pada perlakuan P1 dan terendah pada P3. Walaupun pemberian kulit polong kedelai dalam ransum memiliki nilai $\mathrm{R}-\mathrm{C}$ ternedah tetapi masih menguntungkan karena nilai $\mathrm{R}-\mathrm{C}$ ratio dari masing-masing perlakuan yang memiliki nilai $\mathrm{R}-\mathrm{C}$ ratio $>1$.

\section{Daya Dukung Limbah Kacang Kedelai sebagai Sumber Pakan Ternak}

Daya dukung limbah tanaman pangan merupakan suatu wilayah untuk menghasilkan atau menyediakan pakan berupa limbah tanaman pangan yang dapat menampung kebutuhan sejumlah populasi ternak ruminanansia tanpa melalui pengolahan (Syamsu et al., 2006). Daya dukung limbah tanaman pangan dihitung dengan menggunakan beberapa asumsi kebutuhan ternak ruminansia. Asumsi yang digunakan yaitu satu satuan ternak (1ST) ternak ruminansia rata-rata membutuhkan bahan kering (BK) 6.25 $\mathrm{kg}$ /hari (NRC 1984). Hasil penelitian ini dengan $\mathrm{PBBH}$ terbaik yaitu pada perlakuan P2 dengan menggunakan 15\% dan kulit polong kacang kedelai dan 20\% ampas tahu dalam ransum. Berdasarkan kebutuhan pakan ternak ruminansia tersebut dapat dihitung kapasitas daya dukung ternak berdasarkan produksi limbah yang dihasilkan Tabel 5 .

Daya dukung limbah kacang kedelai sebagai pakan ternak ruminansia (ST) dihitung berdasarkan kebutuhan bahan kering (Tabel 5). Kapasitas daya tampung kulit polong kacang kedelai adalah $8.95 \mathrm{ST}$, sedangkan ampas tahu adalah $1.94 \mathrm{ST}$. Limbah kacang kedelai memiliki potensi untuk dijadikan sebagai pakan ternak ruminansia dengan melihat potensi dan daya dukungnya. Penggunaan limbah tanaman sebagai pakan ternak dalam skala besar memiliki kendala karena memiliki nutrisi yang beragam (Soetanto 2001). Selain itu limbah pertanian mempunyai keterbatasan dalam penggunaannya sebagai pakan ternak karena sebagian memiliki kualitas yang rendah. Upaya untuk meningkatkan nutrisi limbah tanaman dapat dilakukan dengan menggunakan cara fisik, amonisasi, dan mikrobiologis. Namun teknologi yang digunakan harus 
Tabel 5. Daya dukung limbah kacang kedelai sebagai sumber pakan

\begin{tabular}{lc}
\hline Limbah kedelai & Daya dukung (ST) \\
\hline Kulit polong kacang kedelai (ha/tahun) & 8,95 \\
Ampas tahu (ha/tahun) & 1,94 \\
\hline
\end{tabular}

Keterangan : Konsumsi BK KPKK P2 $=342,19$ kg/ekor/tahun, konsumsi BK AT P2, $=456,25 \mathrm{~kg} /$ ekor/tahun. Produksi BK KPKK $=1,75$ ton/ha, dan produksi BK AT $=0,44$ ton $/$ ha

tepat, murah dan praktis agar mudah diadopsi oleh petani.

\section{KESIMPULAN}

Hasil produksi bahan kering limbah kedelai, berupa kulit polong kedelai dan ampas tahu masing-masing 1,75 ton/ha dan 0,44 ton/ha, dan memiliki daya dukung sebagai pakan sapi sebesar $8.95 \mathrm{ST} /$ ha/tahun dan $1.94 \mathrm{ST} / \mathrm{ha} /$ tahun dengan penggunaan $15 \%$ kulit polong kedelai dalam ransum. Hasil analisis ekonomi menunjukkan penggunaan limbah kedelai cukup efisien dan berpotensi sebagai pakan alternatif pengganti hijauan pada sapi madura.

\section{DAFTAR PUSTAKA}

[BPS] Badan Pusat Statistik. 2014. Statistik Indonesia. Badan Pusat Statistik. Jakarta.

[Ditjennak] Direktorat Jendral Peternakan. 2014. Statistik Peternakan. Ditjennak Departemen Pertanian. Jakarta.

[RENSTRA] Rencana Strategis. 2015. RENSTRA Kementerian Pertanian 2015-2019. Kementerian Pertanian. Jakarta.

Asnath, M. F., R. Priyanto, S. Suharti, K. G. Wiryawan, and M. Ismail. 2016. Productivity and Meat Quality of local Cattle Fed Soybean By-Products. Pakistan J. Nutrition 15 (4): 364-369,2016.

Astutik, S.I.B., M. Arifin, \& W.S. Dilaga. 2002. Respon Sapi Po Berbasis Pakan Jerami Padi Terhadap Berbagai Formula "Urea Molases Blok". Seminar Nasional Teknologi Peternakan dan Veteriner. Fakultas Peternakan. Universitas Diponegoro. Semarang.

Haryanto, B., IGM Budiarsana, I. Inounu, dan K. Dwiyanto. 2002. Panduan Teknis Sistem Integrasi Padi-Terna. Badan Litbang Pertanian. Departemen Pertanian.

Kennedy, C., L. Baker, S. Dhakal, A. Ramaswami. 2012. Sustainable urban system an integrated approarch. J. Nutr., 9: 882-826.lokal terhadap income over feed cost.J. Agroland 16 (1) : 72 - 77, Maret 2009.

Luthan, F. 2009. Peluang Pencapaian dan Kebijakan Swasembada Daging 2014. Disampaikan dalam Seminar Tematik HUT Badan Litbang Pertanian Indonesia Keluar dari Perangkap Impor Sapi Potong. Bogor, 12 Agustus 2009.

Matjik, A. A. dan I. M. Sumertajaya. 2002. Perencanaan dan Percobaan dengan Aplikasi SAS dan Minitab. Cetakan ke-2. IPB Press, Bogor.

NRC. 1984. Nutrient Requirement of Beef Cattle. 6th rev. ed. Washington DC: National Academy Press.

Nurdiati., K. E Handayanto. Lutojo. 2012. Efisiensi produksi sapi potong pada musim kemarau di peternakannrakyat daerah pertanian lahan kering kabupaten gunungkidul.Tropical Animal Husbandry Vol. 1 (1), Oktober 2012:52-58

Soetanto H. 2001. Teknologi dan Strategi Penyediaan Pakan dalam Pengembangan Industri Peternakan. Makalah Workshop Strategi Pengembangan Industri Peternakan, Makassar 29-30 Mei 2001. Makassar: Fakultas Peternakan UNHAS dan Puslitbang Bioteknologi LIPI.

Suharno., H. Dan Afandi. 2009. Perbedaan waktu pemberian pakan pada sapi jantan

lokal terhadap income over feed cost.J. Agroland 16 (1) : 72 - 77, Maret 2009.

Syamsu J. A. Ilyas. dan I. Syamsuddin. 2006. Potensi limbah tanaman sebagai sumber pakan sapi potong dalam mendukung integrasi ternak-tanaman di Kabupaten Pinrang, Sulawesi Selatan. Disampaikan pada Seminar Nasional "Peningkatan Akses Pangan Hewani melalui Integrasi Pertanian-Peternakan Berkelanjutan Menghadapi Era ACFTA" dilaksanakan oleh Fakultas Peternakan Universitas Jambi pada tanggal 23 Juni 2010 di Jambi. 